\title{
Hypogammaglobulinaemia and negative anti-HIV antibodies in AIDS
}

\author{
T ESPAÑOL, R GARCIA-ARMUÍ, A BOFILL, J SUÑÉ, AND J M BERTRAN \\ Department of Immunology, Pediatric Hospital, $R S$ Valle Hebrón, Barcelona, Spain
}

SUMMARY Repeated bacterial infections are frequent in children with AIDS owing to the B cell abnormalities produced by HIV infection. We report on two infants who presented with hypogammaglobulinaemia and with no HIV antibodies, but with epidemiological, immunological, and clinical features of AIDS.

Acquired immune deficiency syndrome (AIDS) in childhood, particularly in infants, is different from the adult disease. Epidemiological studies indicate that $18 \%$ of affected children have been transfused with contaminated blood products, $73 \%$ of them have parents who are at risk, and in the rest the source of the virus is unknown. The most common clinical features are chronic pneumonitis, enlarged liver or spleen with or without lymphadenopathy, failure to thrive, and recurrent infections.

It is difficult to distinguish infantile AIDS from some of the congenital immunodeficiency diseases. Shannon and Ammann have suggested that the presence of hypergammaglobulinaemia and human immunodeficiency virus (HIV) antibodies, together with deficiencies in the cellular immune response, strongly support the diagnosis of AIDS, ${ }^{1}$ but hypogammaglobulinaemia with a negative antibody response could, in some cases, be one of the first manifestations of the immunological abnormalities produced by the viral infection.

\section{Case reports}

The first patient was born in 1983 by caesarean section because of maternal isoimmunisation; gestation was 32 weeks and he weighed $1800 \mathrm{~g}$. He had an exchange transfusion on day 1 and another transfusion when he was 1 month old. When he was 5 months old he was admitted to hospital because of failure to thrive, respiratory distress, persistent oral candidiasis, and diarrhoea. Results of laboratory tests showed disseminated cytomegalovirus infection and hypogammaglobulinaemia. When he was 6 months old the diagnoses of severe combined immunodeficiency and sex linked hypogammaglobulinaemia were refuted by a normal lymphocytic response to phytohaemagglutinin and the presence of $B$ and T cells in his blood (Table); he was treated with intravenous gammaglobulin. There was no family history of immune deficiency. He continued to have recurrent bacterial infections and candidiasis and excreted cytomegalovirus. He died

Table Immunological data on the two patients and their blood donors

\begin{tabular}{|c|c|c|c|c|c|}
\hline & \multicolumn{2}{|l|}{ Case No I } & \multirow{2}{*}{$\begin{array}{l}\text { Blood } \\
\text { donor }\end{array}$} & \multirow{2}{*}{$\begin{array}{l}\text { Case No } 2 \\
\text { (age } 4 \text { months) }\end{array}$} & \multirow{2}{*}{$\begin{array}{l}\text { Mother } \\
\text { (donor) }\end{array}$} \\
\hline & (at 6 months) & (at 16 months) & & & \\
\hline Lymphocytes/platelets & Normal/normal & Normal/40000 & Normal/normal & Normal/normal & Normal/normal \\
\hline \multicolumn{6}{|l|}{ Immunoglobulins: } \\
\hline $\operatorname{IgG}(g / 1)$ & $1 \cdot 32$ & 6.90 & $19 \cdot 70$ & 0.95 & $21 \cdot 50$ \\
\hline $\operatorname{IgM}(\mathrm{g} / \mathrm{l})$ & 0.92 & $1 \cdot 18$ & $1 \cdot 38$ & 0.28 & 1.75 \\
\hline $\operatorname{IgA}(\mathrm{g} / 1)$ & 0.16 & $0 \cdot 30$ & 2.96 & 0.12 & 3.48 \\
\hline B cells $(\%)$ & 12 & 0 & 16 & 17 & 14 \\
\hline \multicolumn{6}{|l|}{$T$ cells* $(\%)$} \\
\hline T3 & 42 & 36 & 65 & 21 & 49 \\
\hline $\mathrm{T} 4$ & 30 & 28 & 14 & 11 & 21 \\
\hline T8 & 28 & 46 & 59 & 25 & 43 \\
\hline T4/T8 index & 1.2 & 0.6 & 0.2 & 0.4 & 0.5 \\
\hline Phytohaemagglutinin response index $t$ & 27 & 2 & 43 & 18 & 21 \\
\hline Pokeweed mitogen response index $\dagger$ & 6 & 4 & Not done & 3 & Not done \\
\hline Circulating immune complexes $(\%)$ & Negative & 50 & 18 & 21 & Not done \\
\hline Anti-HIV antibody (ELISA) & Negative & Negative & Positive & Negative & Positive \\
\hline Western blot & Not done & Not done & Positive & Negative & Positive \\
\hline antibody titre & $1 / 128$ & $1 / 64$ & 1/512 & Negative & Negative \\
\hline
\end{tabular}

${ }^{*}$ Indirect immunofluorescence with monoclonal antibody (Ortho); mean (SD) normal values $\left.-\mathrm{T}_{3}=60\right)(8 \%), \mathrm{T}_{4}=42(6 \%), \mathrm{T}_{\mathrm{x}}=21(5 \%) ; \mathrm{inormal}$ valucs: $\mathrm{PHA}$ index $>20$. PWM index $>1 \cdot 0$. fnormal values $<15 \%$. 
at the age of 16 months, at which time he weighed $5.5 \mathrm{~kg}$ and was cachectic. The donor of the blood used for the transfusion was a homosexual positive for HIV antibodies with obvious immunological abnormalities (Table).

The second patient was born at 36 weeks' gestation with intrauterine growth failure weighing $1900 \mathrm{~g}$. He had a blood transfusion at the age of 1 month for anaemia, his mother being the donor. At the age of 4 months he was admitted to hospital with diarrhoea, persistent oral candidiasis, fever, respiratory distress, quadriplegia, and hypertonia. Results of laboratory tests showed hypogammaglobulinaemia and abnormal lymphocyte subpopulations (Table). Candida was isolated from blood and cerebrospinal fluid. Computed tomography showed severe cortical atrophy and calcification of the basal ganglia (Figure). The electroencephalogram was normal, but the brain stem auditory evoked potential was abnormal. He was given gammaglobulin intravenously, but at the time of writing he had repeated bacterial infections. $\mathrm{He}$ weighed $5.2 \mathrm{~kg}$ at the age of 11 months and was severely retarded. His father was a drug addict and both parents were positive for HIV antibodies. The Table shows the mother's immunological data.

\section{Discussion}

The fact that the lymphocytes from both patients

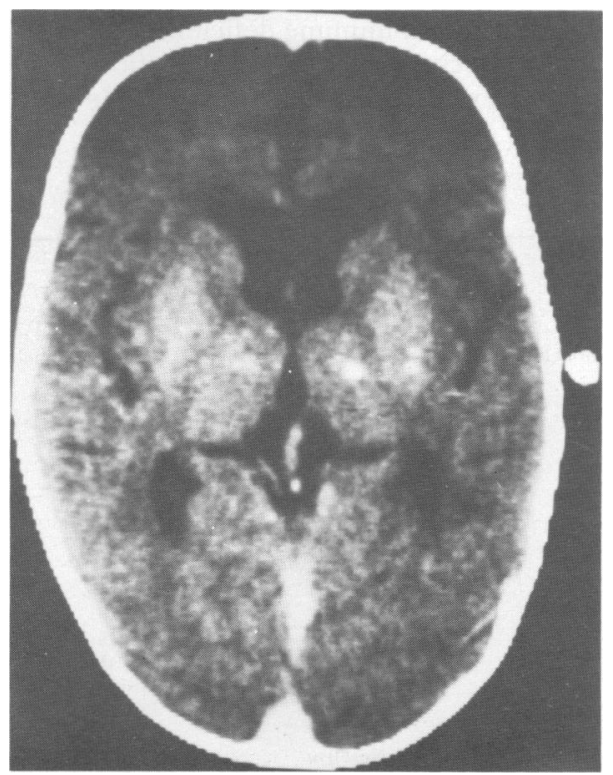

Figure Computed tomogram, case no 2 showing cortical atrophy and small calcifications. initially responded to mitogens and produced IgM and that $T$ and $B$ cells were found, together with the progressive deterioration of the immune responses, indicates that neither had severe combined immune deficiency or agammaglobulinaemia. Both were at high risk of AIDS having had contaminated blood transfusions early in life, and the mother of the second patient was seropositive. ${ }^{2}$

One of the differences between infantile and adult AIDS is the high incidence of bacterial infections in the former. Abnormalities of $\mathrm{T}$ lymphocytes are usually found in the blood of patients with AIDS, but recently abnormalities of $\mathrm{B}$ cell function have been described both in adults and children. ${ }^{3}$ Hypergammaglobulinaemia is more common than hypogammaglobulinaemia. ${ }^{4}$

A 9 year old boy with clinical and laboratory findings consistent with a diagnosis of AIDS has been described, with an atypical antibody response to HIV. ${ }^{5}$ He had raised concentrations of immunoglobulin in his serum and had survived disseminated cryptococcosis, suggesting that infection was by a different retrovirus. In contrast, the blood donor of our first patient and the mother of the second had positive antibodies diagnostic of HIV infection by Western blot analysis.

An immature immune system associated with prematurity could have a bearing on the severity of the $\mathrm{B}$ cell abnormalities in our two patients; prophylaxis and treatment with gammaglobulin should be considered for such patients.

Neurological abnormalities have been reported in patients with AIDS. ${ }^{6}$ Cortical atrophy and calcification on computed tomography are common findings, but in future culture and identification of the virus will have to be done to confirm the diagnosis.

\section{References \\ 'Shannon KM. Ammann AJ. Acquired immune deficiency syndrome in childhood. J Pediatr 1985;106:332-42. \\ Church JA. Isaacs H. Transfusion-associated acquired immune deficiency syndrome in infants. J Pediatr 1984;105:731-7. \\ ${ }^{3}$ Pahwa S. Fikrig S. Menez R et al. Pediatric acquired immuno- deficiency syndrome: demonstration of $B$ lymphocyte defects in vitro. Diagn Immunol 1986:4:24-30. \\ + Rubinstein A. Sicklick M. Gupta A. et al. Acquired immuno- deficiency with reversed $T_{4} / T_{x}$ ratios in infants born to promiscuous and drug-addicted mothers. JAMA 1983;249: $2350-6$. \\ Sippard MJ. Dalgleish A. Gibson P. Malkovsky M. Web- ster ADB. Acquired immunodeficiency with disseminated cryptococcosis. Arch Dis Child 1986;61:289-302. \\ "Belman AL. Ultmann MH. Horoupian D. et al. Neurological complications in infants and children with acquired immune deficiency syndrome. Ann Neurol 1985:18:560-6.}

Correspondence to Dr T Español. Department of Immunology, Pediatric Hospital. R S Valle Hebrón. Barcelona, 08035. Spain.

Received 2 March 1987 